\title{
Genetic relationship and similarity of some selected chicken strains
}

\author{
K. N. Monira, M. N. Islam, R. Khatun and S. Ahmed \\ Poultry Production Research Division, Bangladesh Livestock Research Institute, Savar, Dhaka-1341, E-mail: \\ monirablri@yahoo.com
}

\begin{abstract}
Random amplified polymorphism DNA (RAPD) technique was applied to detect genetic similarity between seven local chicken strains selected for eggs and meat production in Bangladesh. Conservation and improvement strategies ought to be based on proper genetic characterization in association with phenotypic characterization. White Leghorn, White Rock, Rhode Island Red, and Barred Plymouth Rock fall under recognized strain and Hilly, Deshi and Necked Neck fall under native bird group. Based on four oligonucleotide primers, the genetic similarity between the eggproducing strains (White Leghorn; White Rock; Rhode Island Red and Barred Plymouth Rock) was between 81.3 to $89.3 \%$. While the genetic similarity of three native chicken strains selected for meat production (Hilly, Deshi and Necked Neck) was 69.0 to $78.7 \%$ similar based on the RAPD Marker. So, RAPD markers appeared to be effective in detecting similarity between chicken strains and they provide a potential tool for studying the inter-strain genetic similarity.
\end{abstract}

\section{Keywords: Chicken, Local strains, RAPD-PCR, Genetic similarity}

\section{Introduction}

Bangladesh has a rich heritage of native poultry germplasm, which strongly supported decisive measures for conserving native genetic resources. These native chickens have some morphological characters such as naked neck, frizzles, dwarfism etc., which have direct and indirect effect on tropical adaptability. Morphological characteristics and production performance variations of some Bangladeshi chickens have been reported by Howlider et al., 1995 and Islam et al., 2009. A few reports are available based on DNA polymorphism regarding Bangladeshi indigenous chicken RAPD markers can be applied to generate genotype-specific banding patterns. The use of DNA marker technology in poultry as a strains identification has progressed rapidly during the last decade. The effectiveness of RAPD in detecting polymorphism between chicken populations and their applicability in population studies and establishing genetic relationships among chicken populations have been reported by Sharma et al. 2001. For the discrimination of genetic resources of economically important Bangladeshi animals such as poultry, and other farm animals. This technique is playing a significant role in the strains protection law. RAPD assay is simple, fast and comparatively low-cost. It has quickly become the method of choice for genotype identification, population and pedigree analysis, phylogenic studies and genetic mapping. They have earlier demonstrated the genetic variability in 17th generation of Japanese quail selected for high eggs and meat production (Ali et al., 2002) In poultry, RAPD has been used to detect specific markers (Zhang et al. 1995) to estimate genetic relatedness among various poultry species (Sharma et al., 1998, Smith et al., 1996), as well as for genome mapping (Levin et al., 1993). They have also presented some preliminary data showing molecular differences between Egyptian chicken strains (Ali and Ahmed, 2001) and indicating the potential use of RAPD markers for a wide range of applications in poultry breeding. According to Howard and Moore (1984), there are various well-developed strains of poultry that are used commercially. However, information about the genetic characterization of these strains and the amount of genetic diversity among them is minimal.

Therefore, the present study was performed to characterize these strains genetically and to estimate the genetic variability between them in order to enhance selection and breeding. 


\section{Materials and Methods}

Sample collection: A total of 70 blood samples were collected from seven different selected chicken strains, WL, WR, RIR, BPR, Hilly, Deshi and Nacked Neck. Blood samples were collected from Poultry Production Research Division, Bangladesh Livestock Research Institute, Savar, Dhaka, Bangladesh. At least $5 \mathrm{ml}$ of fresh blood sample was collected from each of the chicken aseptically by puncturing jugular vein in EDTA containing Vacutainer. The blood was gently mixed with anticoagulant, and kept on ice to maintain low temperature in order to prevent cell lysis. Subsequently the blood samples were transported to the laboratory and stored at $-20^{\circ} \mathrm{C}$ until the isolation of genomic DNA.

Genomic DNA extraction: The genomic DNA was extracted from whole blood following the modified of Standard Saline Citrate Buffer method as described. The isolated DNA was checked by mini-gel method. DNA extraction was carried out by method of Roe et al. 1996. The concentration of DNA and its relative purity were determined using a spectro-photometer based on absorbance at 260 and $280 \mathrm{~nm}$ respectively (Huberman, 1995). The polymerase chain reaction (PCR) mixture (25 micro-L) consisted of $0.33 \mathrm{U}$ of Taq DNA polymerase, $2.5 \mathrm{mmol}$ dNTPs, and $25 \mathrm{pmol}$ of random primer, PCR Buffer 10x and $40 \mathrm{ng}$ of genomic DNA.

PCR amplification and electrophoresis: Blood sample mixed with SSC buffer solution and centrifuged two times at 13,000 rpm for 5 minutes. Then $375 \mu \mathrm{l} 0.2 \mathrm{M}$ Sodium acetate, $25 \mu \mathrm{l} 10 \%$ SDS and $5 \mu \mathrm{l}$ Proteinase- $\mathrm{K}$ was added and incubated at $55^{\circ} \mathrm{C}$ temperature for 1 hour. Then $20 \mu \mathrm{I}$ PCIA solution was added and mixed and centrifuged at $13,000 \mathrm{rpm}$ and aqueous layer saved and DNA was precipitated by $100 \%$ ethanol and $180 \mu \mathrm{I} \mathrm{TE} \mathrm{(10:1)} \mathrm{buffer} \mathrm{and} \mathrm{incubated} \mathrm{at} 55^{\circ} \mathrm{C}$ temperature for 10 minutes. Add $20 \mu \mathrm{l} 2$ $\mathrm{M}$ sodium acetate mixture and centrifuged at $13,000 \mathrm{rpm}$. Then wash with $70 \%$ ethanol and Dry the pellet in DNA concentrator for 15 minutes to remove alcohol and resuspend the pellet by adding $150 \mu \mathrm{LE}$ (10:1) buffer solution and incubated at $55^{\circ} \mathrm{C}$ temperature overnight and Stored at $-20^{\circ} \mathrm{C}$.

The reaction mixture was placed on a DNA thermal cycler (Perkin Elmer 9700). The PCR Programmed an initial denaturation step at $94{ }^{\circ} \mathrm{C}$ for 5 mins followed by 30 cycles with $94^{\circ} \mathrm{C}$ for 30 seconds for DNA denaturation, annealing as mentioned with each primer, extension at $72{ }^{\circ} \mathrm{C}$ for 1 mins and final extension at $72{ }^{\circ} \mathrm{C}$ for 10 minutes were carried out. The amplified DNA fragments were separated on $2 \%$ agarose gel and stained with ethidium bromide. The amplified pattern was visualized on a UV transilluminator and photographed.

The RAPD bands were scored for their presence (1) or absence (0). The index of similarity between each two strains was calculated using the formula: $\mathrm{Bab}=2 \mathrm{Nab} /(\mathrm{Na}+\mathrm{Nb}))$, where $\mathrm{Nab}$ is the number of common fragments observed in individuals $\mathrm{a}$ and $\mathrm{b}$, and $\mathrm{Na}$ and $\mathrm{Nb}$ are the total number of fragments scored in $\mathrm{a}$ and b, respectively ( Lynch, 1990). The similarity index was calculated for each primer separately, and the average for all primers was carried out with each comparison.

Genetic data analysis: The PCR amplified bands were scored visually by two independent persons on the basis of their presence or absence. Band sharing based intra-population similarity indicates (Si) were calculated for all possible comparisons according to the following formula:

Similarity index $(\mathrm{Si})=2 \mathrm{Nab} /(\mathrm{Na}+\mathrm{Nb})$

Where, $\mathrm{Nab}$ is the total number of RAPD band shared by individuals $\mathrm{a}$ and $\mathrm{b}$. $\mathrm{Na}$ and $\mathrm{Nb}$ are the numbers of fragments scored for each individuals, respectively (Lynch, 1990).

\section{Result and Discussion}

Among Six primers screened, four successfully amplified genomic DNA from samples of chicken strains (Table 1, Fig. 1). The estimated genetic similarity between the chicken strains is presented in Table 2. The genetic similarity between the two egg-producing strains (White Leghorn and White Rock) and (Rhode Island Red and Barred Plymouth Rock) was between 81.3 to $89.3 \%$. While the three native 
chicken strains selected for meat producing (Hilly, Deshi and Necked Neck) was 69.0 to $78.7 \%$ similar based on the RAPD Marker. The intra-population similarity indicates were relatively high in the exotic chicken compared to the native ones.

Table 1. The sequence of the primers used and their annealing temperatures

\begin{tabular}{|c|l|c|}
\hline Primer & \multicolumn{1}{|c|}{ Sequence } & Annealing Tm/sec \\
\hline 1 & AGG CCC CTG T & $34 / 30$ \\
\hline 2 & AAA GCT GCG G & $30 / 30$ \\
\hline 3 & GAA ACG GGT GGT GAT CGC AG & $50 / 30$ \\
\hline 4 & GGT GAC GCA GGG GTA ACG CC & $55 / 30$ \\
\hline
\end{tabular}

Table 2. Genetic similarity estimated for each primer between strains

\begin{tabular}{|l|c|c|c|c|c|}
\hline \multirow{2}{*}{ Comparisons } & \multicolumn{5}{|c|}{ Primer Number } \\
\cline { 2 - 6 } & 1 & 2 & 3 & 4 & Average \\
\hline WL/ WR & 0.89 & 0.933 & 0.89 & 0.857 & 0.893 \\
\hline RIR/BPR & 0.769 & 0.857 & 0.792 & 0.833 & 0.813 \\
\hline Hilly / Deshi & 0.60 & 0.769 & 0.60 & 0.792 & 0.690 \\
\hline Hilly / Necked Neck & 0.769 & 0.833 & 0.769 & 0.780 & 0.787 \\
\hline
\end{tabular}

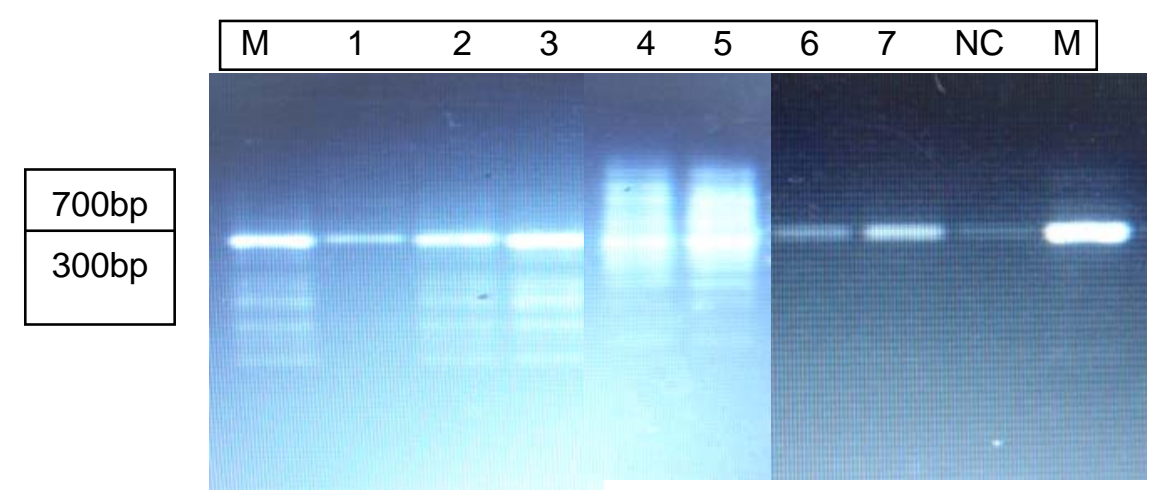

Fig. 1. RAPD amplification products generated by Primer 4. Lane M: DNA marker; Lane 1: WL; Lane 2: WR; Lane 3: RIR; Lane 4: BPR; Lane 5: Hilly: Lane 6: Deshi and Lane 7: Necked Neck, Negative control and DNA marker

\section{Conclusion}

It can be concluded from our study that RAPD markers are effective in detecting similarity between chicken strains and they provide a potential tool for studying the inter-strain genetic similarity and the establishment of genetic relationships.

\section{References}

Ali, B.A. and Ahmed, M.M.M. 2001. Random amplified polymorphic DNA in some chicken strains. First conference of Role of Biochemistry in Environment and Agriculture, PP 23-31, Part 1. Cairo University, Egypt.

Ali, B.A., Ahmed, M.M.M., Bahie El-Deen, M. and Shalan H.M. 2002. Genetic variability in the $17^{\text {th }}$ generation of Japanese quail selected for high eggs and meat production. Egypt. J. Poult. Sci. Vol; 22: 59-71.

Howard, R. and Moore, A. 1984. A Complete Checklist of Birds of the World, revised ed. London, MacMillan.

Huberman, J.A. 1995. Importance of measuring nucleic acid absorbance at 240nm as well as 260 and 280nm. Biotech. 18.4: 634.

Howlider, M.A.R., Begum, F., Islam, M.S. and Wahid, M.A. 1995. Feathering and meat yield of full feathered and naked neck indigenous chicken of Bangladesh. J. Applied Animal Research, 1:191-195. 
Islam, M.A. and Nishibori, M. 2009. Indigenous baked neck chicken: a valuable genetic resource for Bangladesh. World Poultry Science Journal, 65: 125-138.

Levin, I., Crittenden, L.B., Dodgson, J.B. 1993. Genetic map of the Z chromosome using random amplified polymorphic DNA (RAPD) markers. Genomics, Vol; 16: $224-230$.

Lynch, M. 1990. The Similarity Index and DNA Fingerprinting.Mol.Biol.Evol. Vol; 7:478-484.

Roe, B.A., Crabtree, J.S. and Khan, A.S. 1996. Genomic DNA Isolation from blood. In DNA Isolation and Sequencing: Essential techniques. John Wiley \% Soons Ltd. Baffins Lane. Chichester, West Sussex PO19 1UD, UK.

Sharma, D. Appa Rao, K.B.C, Singh, R.V. and Totey, S.M. 2001. Genetic diversity among chicken breeds estimated through randomly amplified polymorphic DNA. Anim. Biotechnol. Vol; 12: 111-120.

Sharma, D., Appa Rao, K.B.C., Singh, H.P., Totey, S.M. 1998. Random amplified polymorphic DNA (RAPD) for evaluating genetic relationship among guinea fowl varieties. Genetical Analysis: Bimolecular Engineering.

Sharma, D., Appa Rao, K.B.C. and Totey, S.M. 2000. Measurement of within and between population genetic variability in quails. Br. Poult. Sci. Vol ;41: 29- 32.

Smith, E.J., Jones, C.P., Bartlett, J. and Nestor, K.E.. 1996. Use of randomly amplified polymorphic DNA markers for the genetic analysis of relatedness and diversity in chickens and turkeys. Poult. Sci. Vol; 75: 579-584.

Zhang, X., Mcdaniel, C.R. and Giamborne, J.R. 1995. Random amplified polymorphic DNA comparisons among broiler lines selected for incidence of tibia dyschondroplasia. Poult. Sci. Vol; 74: 1253-1258. 